The Making of a Social Disease 



\section{The Making of a Social Disease}

Tuberculosis in NineteenthCentury France

David S. Barnes

UNIVERSITY OF CALIFORNIA PRESS Berkeley - Los Angeles · London 
University of California Press

Berkeley and Los Angeles, California

University of California Press

London, England

Copyright (C) 1995 by The Regents of the University of California

Library of Congress Cataloging-in-Publication Data

Barnes, David S.

The making of a social disease : tuberculosis in nineteenthcentury France / David S. Barnes

p. $\mathrm{cm}$.

(8)

Includes bibliographical references and index.

ISBN 0-520-08772-0 (cloth : alk. paper)

1. Tuberculosis-France-History-19th century. I. Title

[DNLM: 1. Tuberculosis-history-France. 2. History of Medicine,

19th Cent.-France. 3. Disease Outbreaks-history-France.

4. Socioeconomic Factors. WF 11 GF7 B2m 1995]

RC316.F8B37 1995

614.5'42'094409034-dc20

DNLM/DLC

for Library of Congress

94-15230

CIP

Printed in the United States of America

$\begin{array}{lllllllll}1 & 2 & 3 & 4 & 5 & 6 & 7 & 8 & 9\end{array}$

The paper used in this publication meets the minimum requirements of American $\mathrm{Na}$ tional Standard for Information Sciences-Permanence of Paper for Printed Library Materials. ANSI Z39.48-1984 
To my parents,

Richard and Helena Barnes,

and to the memory of my grandmother,

Helena Borcic,

and my great-grandmother,

Rose Stepanek 
